\title{
A STUDY OF MAJOR AND TRACE ELEMENT ACCUMULATION IN HUMIC ACIDS
}

\author{
Diana Dudare, Oskars Purmalis, Maris Klavins \\ University of Latvia, Department of Environmental Science \\ Raina blvd. 19, LV 1586, Riga, Latvia \\ Ph: +(371)67332704, fax: +(371)67332704, e-mail: dianadudare@inbox.lv
}

\begin{abstract}
It has been widely studied recent as well as historic accumulation of elements in peat profiles depending on intensity of anthropogenic pollution and thereby peat profiles serve as archives for research of environmental change. Peat ability to accumulate major and trace elements depends on the character of element supply, potency of metal ions to bind functionalities in the peat structure, $\mathrm{pH}$ reaction, oxygen presence, presence of complexing compounds, inorganic ions and many other factors. The aim of this study is to assign major and trace element distribution in humic acids (HA) for two well characterized ombrotrophic peat profiles of Eipurs and Dzelve Bog and analyse factors affecting element concentration in peat humic acids. Elemental and functional analysis of the isolated HAs was done, using total reflection X-ray spectrometry, Elemental Analyzer Model EA - 1108, Thermospectronic Helios $\gamma$ UV (Thermo Electron Co.) spectrophotometer, Total acidity method.
\end{abstract}

Keywords: humic acids, peat, trace and major elements, $X$-ray fluorescence spectroscopy.

\section{Introduction}

Major and trace element presence in peat are of importance as an indicator of peat genesis and organic matter humification processes and for industrial use of peat [1]. Upper peat layer of ombrotrophic type bog receive chemical elements only from atmosphere and thus reflect their presence in air [2]. Trace element accumulation in peat profiles has been used to reconstruct changes of human pollution and track down sources and characterize intensity of anthropogenic pollution. It has been widely studied recent as well as historic accumulation of many trace elements in peat profiles depending on intensity of anthropogenic pollution $[3,4$, 5]. Peat ability to accumulate major and trace elements depends on the character of element supply (whether in particulate or ionic form) potency of metal ions to bind functionalities in the peat structure, $\mathrm{pH}$ reaction, oxygen presence, presence of complexing compounds, inorganic ions and many other factors [3, 4]. It has been hypothesized, that the main factor affecting metal accumulation in peat profile are humic substances $[6,7,8,9]$.

Humic substances (HS) are a general category of naturally occurring, biogenic, heterogeneous organic substances that can be generally characterized as yellow to black in colour, of high molecular weight, and refractory to degradation [10]. Humic substances consist of several groups of substances, that depending on their solubility, can be grouped as humic acid (HA) (the fraction insoluble in water under acidic conditions $\mathrm{pH}<2$, but is soluble at greater $\mathrm{pH}$ ) and fulvic acid is the fraction soluble in water at all $\mathrm{pH}$ values [11]. In peat organic matter composition dominates humic acids. HS form most of the organic component of peat and they play a major role in the biogeochemical cycling of many trace elements [12] due to significant complex forming ability. The character of the complex formation between humic acids and major and trace elements is an object of intensive studies during last decades [13, 14, 15, 16]. Thus analysis of trace and major elements in humic substances might help to understand the character of their binding with natural organic matter and processes influencing their cycling in the environment. Knowledge on trace element concentrations in humic substances is also of importance considering their growing use in industry and agriculture. Until now trace and major element concentrations has been analysed in aquatic humic substances [17], sedimentary humic acids [18] and peat humic acids [8,9]. 
The aim of this study is to assign major and trace element distribution between peat and peat humic acids from two well characterized ombrotrophic bog profiles and analyse factors affecting element concentrations in peat humic acids.

\section{Materials and methods}

Materials. Analytical quality reagents (Merk Co., Sigma - Aldrich Co., Fluka Chemie AG $\mathrm{RdH}$ Laborchemikalien GmbH Co.) were used without purification. For preparation of solutions high purity water Millipore Elix 3 (Millipore Co.) $10-15 \mathrm{M} \Omega \mathrm{cm}$ was used throughout.

Peat sampling and characterization, isolation of humic acids. Peat profiles were obtained from well characterized $[19,20]$ ombrotrophic bogs Eipurs and Dzelve. Trace elements in 1 $\mathrm{cm}$ section of peat profile were determined after nitric acid digestion by GFAAS [21]. For isolation of humic acids, the obtained peat profiles were separated into layers by $10 \mathrm{~cm}$ layers and humic acids were isolated using the procedures recommended by the International Humic Substances Society (IHSS) [22].

Characterization peat of humic acids. Elemental analysis $(\mathrm{C}, \mathrm{H}, \mathrm{N}, \mathrm{S}, \mathrm{O})$ was carried out using an Elemental Analyzer Model EA - 1108 (Carlo Erba Instruments). UV/Vis spectra were recorded on a Thermospectronic Helios $\gamma$ UV (Thermo Electron Co.) spectrophotometer in a $1-\mathrm{cm}$ quartz cuvette. An automatic titrator tiroLine easy (Schott - Gerate $\mathrm{GmbH}$ ) was used to measure carboxylic and total acidity of each humic acid. Ba hydroxide method [23, 24] was used to designate of the total amount of carboxylic groups and total acidity. Ba hydroxide method: in $10 \mathrm{ml}$ of test tubes weigh $20 \mathrm{mg}$ of humic acids, adding $10 \mathrm{ml}$ of $0.1 \mathrm{~N}$ $\mathrm{Ba}(\mathrm{OH})_{2}$ solution $\left(\mathrm{CO}_{2}\right.$ free $)$ and place in a manual shaker for 24 hours. After a certain time to each shaken solution add one drop of phenolphthalein until samples coloured purple. Each solution is titrated with standardized $0.1 \mathrm{~N} \mathrm{HCl}$ to $\mathrm{pH} 8.4$ (solution remains colorless). Trace element $(\mathrm{Ti}, \mathrm{Sr}, \mathrm{Se})$ concentrations were measured with total - reflection X-ray fluorescence spectrometry (TXRF) [25]. Samples of humic acid were prepared: $25 \mathrm{mg}$ HA estimated with 1 $\mathrm{ml}$ conc. $\mathrm{HNO}_{3}$ and boiled, until the solution completely evaporated. Using $1 \mathrm{ml}$ burette was instilled $1 \mathrm{ml} 50 \% \mathrm{HNO}_{3}$. The samples were cooled.

$10 \mathrm{mg} \mathrm{l}^{-1}$ of Ga internal standard (Sigma-Aldrich Co.) was added to each sample of $190 \mathrm{ml}$. To get complete results of X-ray fluorescence spectrometry, samples were applied three times on each quartz glass, samples were dried, using Labconco liofilizator. Analyzed samples were placed into total-reflection X-ray fluorescence spectrometer with a 1000 second measurement period.

\section{Results and discussion}

The correlation matrix calculated for metals analyzed in the bog of Eipurs is presented in Table 1. The correlation matrix between metal concentrations in peat core and humic substances of Eipurs, was observed in the tightest correlation between element content of Fe, $\mathrm{Zn}, \mathrm{Cu}$ and $\mathrm{Ca}$. The element pairs $\mathrm{Fe}-\mathrm{Ca}, \mathrm{Cu}-\mathrm{Fe}, \mathrm{Mn}-\mathrm{Zn}, \mathrm{As}-\mathrm{Mn}, \mathrm{Ca}-\mathrm{Cu}$ were all significantly correlated in humic substances of Eipurs bog. The element in peat core of Eipurs had strongest correlation among element pairs $\mathrm{Fe}-\mathrm{Ca}, \mathrm{Mn}-\mathrm{As}, \mathrm{Zn}-\mathrm{Pb}, \mathrm{Cu}-\mathrm{Ni}, \mathrm{Ca}-\mathrm{Ni}$, $\mathrm{Pb}-\mathrm{K}, \mathrm{Ni}-\mathrm{As}$ (Table 1). It has been noticed that close correlations were between the element pairs of natural origin in peat core of Eipurs, for instance, $\mathrm{Fe}-\mathrm{Mn}, \mathrm{K}-\mathrm{Pb}, \mathrm{Ca}-\mathrm{As}$. Correlations such as $\mathrm{Cu}-\mathrm{Cr}, \mathrm{Fe}-\mathrm{Ni}, \mathrm{Mn}-\mathrm{Cu}, \mathrm{Ni}-\mathrm{Mn}$ might be ascribed to industrial activity and long - range transport of pollutants. Comparison of distribution of metals between peat and its humic acid fraction reveals seeming similarity, however, if analyzing correlations between metal concentrations in peat and peat humic acids it becomes evident that there are tight correlations between metals in peat and in humic acid (for example in case of $\mathrm{Cu}$ and $\mathrm{Fe}$ ), but for some elements (for example, As, $\mathrm{K}$ ) these correlations are weak. 
Table 1.

\section{Correlation coefficient matrix of major and trace element analyses in peat and humic} acids (HAs) of Eipurs Bog

\begin{tabular}{|c|c|c|c|c|c|c|c|c|c|c|c|c|c|c|c|}
\hline $\mathrm{Fe}-\mathrm{HA}$ & 0.69 & & & & & & & & & & & & & & \\
\hline$M n-P$ & 0.92 & 0.72 & & & & & & & & & & & & & \\
\hline $\mathrm{Mn}-\mathrm{HA}$ & -0.09 & 0.08 & 0.21 & & & & & & & & & & & & \\
\hline $\mathrm{Zn}-\mathrm{P}$ & -0.30 & 0.02 & 0.08 & 0.67 & & & & & & & & & & & \\
\hline $\mathrm{Zn}-\mathrm{HA}$ & -0.32 & 0.03 & -0.01 & 0.65 & 0.88 & & & & & & & & & & \\
\hline $\mathrm{Cu}-\mathrm{P}$ & 0.75 & 0.63 & 0.77 & -0.08 & -0.15 & -0.21 & & & & & & & & & \\
\hline $\mathrm{Cu}-\mathrm{HA}$ & 0.62 & 0.82 & 0.66 & -0.09 & -0.12 & -0.17 & 0.85 & & & & & & & & \\
\hline $\mathrm{Ca}-\mathrm{P}$ & 0.97 & 0.63 & 0.85 & -0.23 & -0.43 & -0.46 & 0.79 & 0.67 & & & & & & & \\
\hline $\mathrm{Ca}-\mathrm{HA}$ & 0.59 & 0.71 & 0.51 & -0.32 & -0.23 & -0.17 & 0.68 & 0.73 & 0.64 & & & & & & \\
\hline $\mathrm{Pb}-\mathrm{P}$ & -0.23 & 0.08 & 0.08 & 0.91 & 0.75 & 0.74 & -0.02 & 0.03 & -0.36 & -0.19 & & & & & \\
\hline $\mathrm{Pb}-\mathrm{HA}$ & -0.26 & -0.17 & -0.15 & 0.17 & 0.19 & 0.17 & -0.15 & -0.14 & -0.27 & -0.03 & 0.15 & & & & \\
\hline $\mathrm{Ni}_{1}-\mathrm{P}$ & 0.95 & 0.77 & 0.93 & -0.02 & -0.19 & -0.24 & 0.89 & 0.78 & 0.93 & 0.67 & -0.08 & -0.19 & & & \\
\hline $\mathrm{Ni}-\mathrm{HA}$ & -0.01 & 0.01 & -0.05 & -0.08 & -0.06 & -0.06 & -0.19 & -0.18 & -0.09 & -0.39 & -0.18 & -0.12 & -0.04 & & \\
\hline As - P & 0.95 & 0.69 & 0.96 & 0.16 & -0.05 & -0.09 & 0.72 & 0.56 & 0.87 & 0.49 & 0.05 & -0.21 & 0.93 & 0.09 & \\
\hline \multirow[t]{2}{*}{ As - HA } & 0.19 & 0.29 & 0.40 & 0.69 & 0.59 & 0.63 & -0.02 & -0.03 & -0.02 & -0.13 & 0.62 & 0.35 & 0.18 & 0.09 & 0.42 \\
\hline & $\mathrm{Fe}-\mathrm{P}$ & $\mathrm{Fe}-\mathrm{HA}$ & $M n-P$ & $\mathrm{Mn}-\mathrm{HA}$ & $\mathrm{Zn}-\mathrm{P}$ & $\mathrm{Zn}-\mathrm{HA}$ & $\mathrm{Cu}-\mathrm{P}$ & $\mathrm{Cu}-\mathrm{HA}$ & $\mathrm{Ca}-\mathrm{P}$ & $\mathrm{Ca}-\mathrm{HA}$ & $\mathrm{Pb}-\mathrm{P}$ & $\mathrm{Pb}-\mathrm{HA}$ & $\mathrm{Ni}_{1}-\mathrm{P}$ & $\mathrm{Ni}_{1}-\mathrm{HA}$ & As - P \\
\hline
\end{tabular}

The absolute values of element concentration and their intervals determined in peat of Latvia are in general similar to that reported in Estonia, Sweden, Belgium, and other countries; at the same time, the data reflect the local processes affecting element concentrations in the peat mass. This may be related to major elements $(\mathrm{Na}, \mathrm{K})$, which are found in lower concentrations than, for example, in Norway, where sea salt aerosol - containing precipitation causes elevated concentrations of them, as well as to elements such as $\mathrm{Ca}, \mathrm{Mg}$, and Fe. In the peat bulk mass, which is of industrial importance, the trace element concentration is low, especially if compared with element concentrations in other countries. This aspect may be of importance considering the industrial uses of peat in agriculture.

Two studied bogs have very much differing botanical composition, variability of the peat decomposition degree (Fig. 1) and thus study of metal accumulation in their peat, properties and metal accumulation character in humic acids, isolated from peat can reveal the metal binding character during bog development and factors controlling it. A significant contribution to major and trace element binding in peat humic acids can provide their structural features and functional groups, reflected as in their elemental $(\mathrm{C}, \mathrm{H}, \mathrm{N})$ and functional $(\mathrm{COOH})$ composition (Fig. 1). The elemental composition of studied humic acids reflect their original material and is characterized with an increasing values of $\mathrm{C}$ in humic acids from peat with higher decomposition degree, but $\mathrm{H}$ and $\mathrm{N}$ content is fluctuating between values, common for peat humic acids and do not show any well expressed trends of changes within the peat profiles. Carboxylgroup concentration is lower in the humic acids from uppermost peat layers and can reach even values $>6 \mathrm{mEq} \mathrm{g}^{-1}$ in humic acids isolated from peat with higher decomposition degree.

Concentration distribution of major and trace elements between peat and humic acids isolated from peat significantly differs depending on the element (Fig. 3): if concentrations of several elements (supposedly of natural origin such as $\mathrm{Ca}, \mathrm{Fe}, \mathrm{K}, \mathrm{Mn}$ ) in peat are higher than in humic acids, then concentrations of other elements (supposedly of anthropogenic origin such as $\mathrm{Pb}, \mathrm{As}, \mathrm{Cr}, \mathrm{Ni}, \mathrm{Cu}$ ) are higher in humic acids than in peat. Comparison of element concentrations in humic acids found in our study and in other humic acids samples, including reference samples Waskish and Pahokee indicates the major importance of the source on the element on its presence in humic acids. Highest major and trace element concentrations were common for humic acids isolated from sea sediments. In humic acids isolated from peat, major and trace element concentrations depend on their presence in natural bog environment (for example, relatively high variability of $\mathrm{Fe}, \mathrm{Br}, \mathrm{Zn}, \mathrm{Ti}$ ), however concentrations of elements associated with recent human pollution are at relatively similar level. Major and 
trace element concentration changes in humic acids from peat profiles from studied bogs follow to general patterns: a) elements with increased concentrations in humic acids from upper layers of bog $(\mathrm{Zn}, \mathrm{Pb}, \mathrm{Ni}, \mathrm{Cr}, \mathrm{Cu}), \mathrm{b})$ elements with increased concentrations in humic acids from the bog bottom ( $\mathrm{Fe}, \mathrm{Ca}, \mathrm{Mn}, \mathrm{Mg}$ ) and c) elements with elevated concentrations in bottom and upper layers in the humic acids in respect to their concentration in the middle part of the bog (K, As). Similar major and trace element accumulation pattern was previously found to be common for raised bogs and can be interpreted as accumulation of metals due to anthropogenic pollution in the upper layers, due to supply with groundwater from the bottom of the bog.

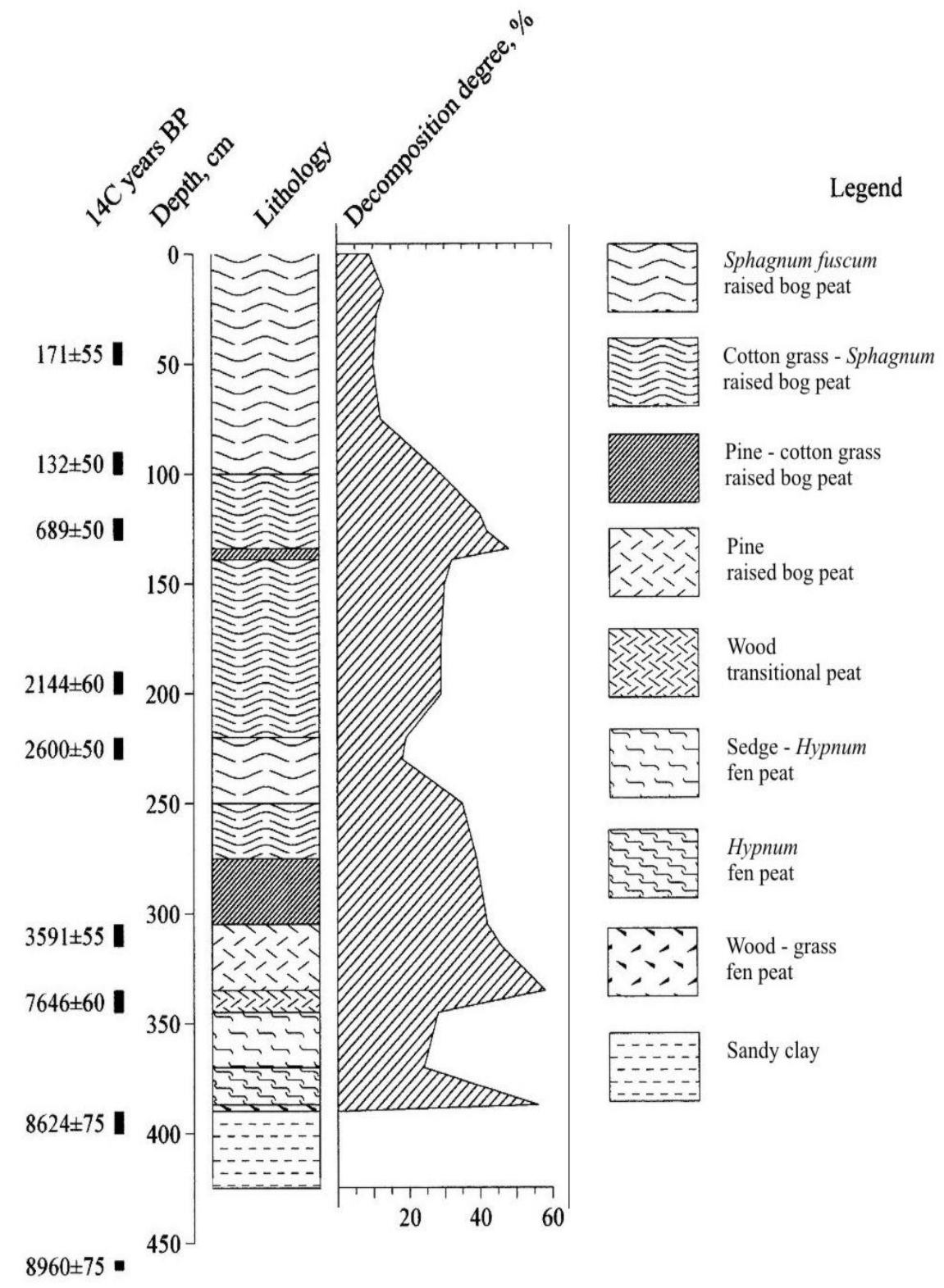

Fig. 1A. Peat stratigraphy and peat decomposition degree in Eipurs bogs 


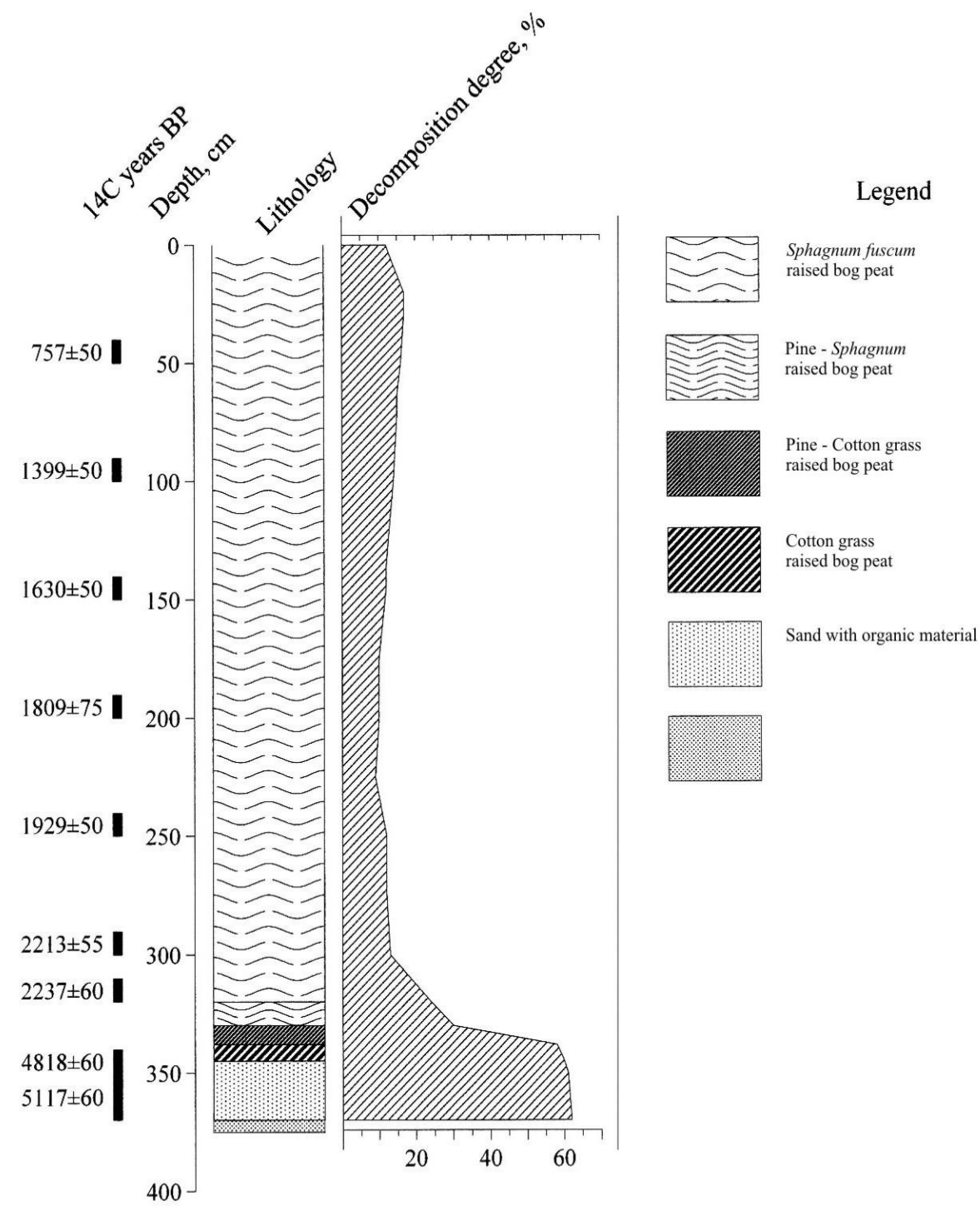

Fig. 1B. Peat stratigraphy and peat decomposition degree in Dzelves bogs

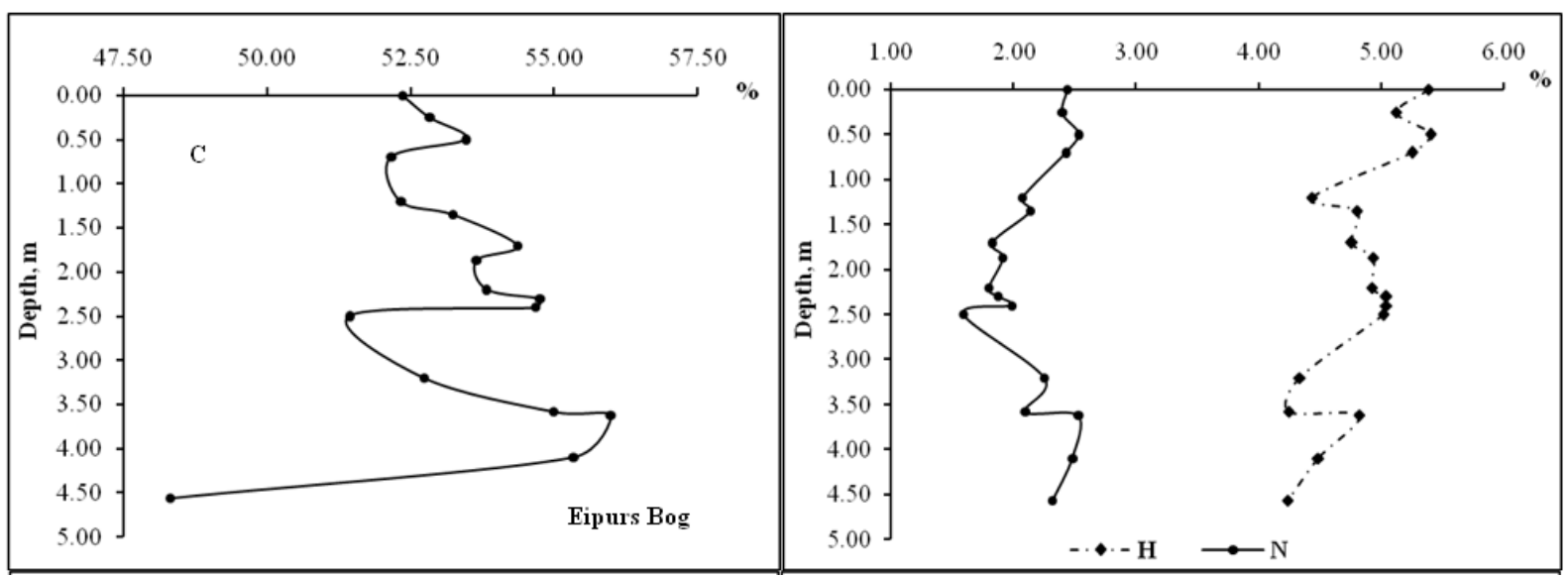

Fig. 2A. Elemental composition of humic acids from Eipurs bogs 


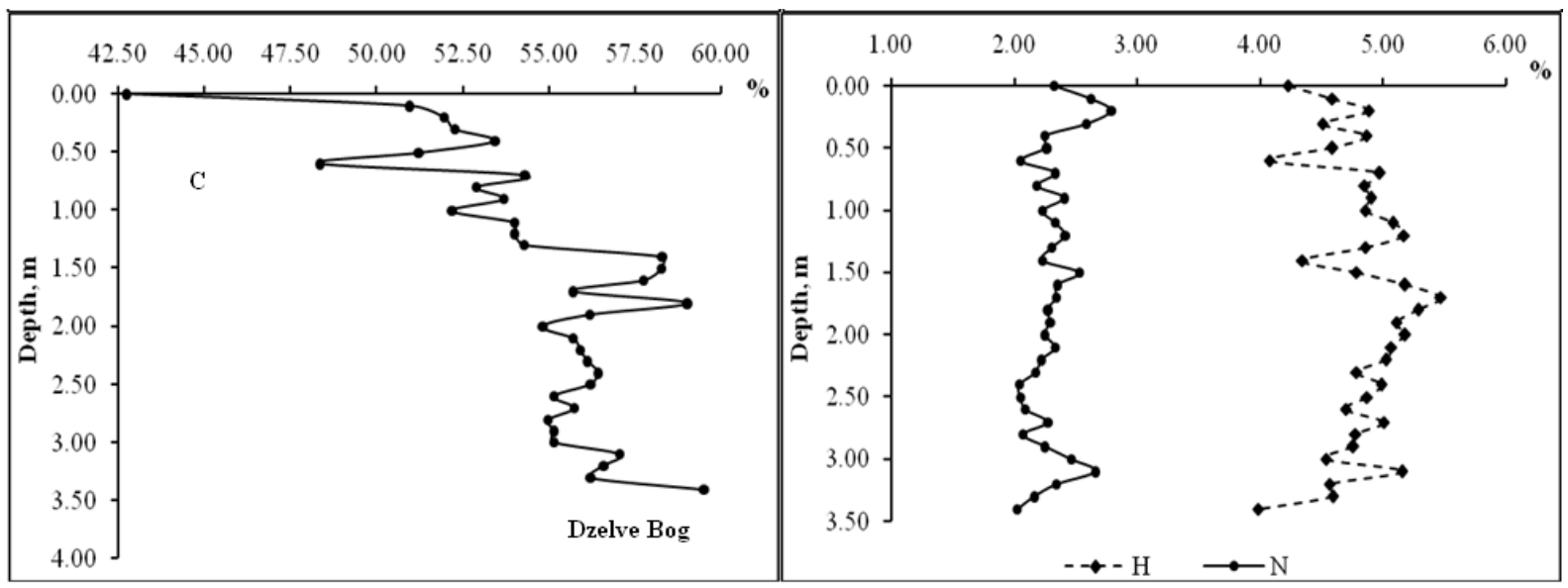

Fig. 2B. Elemental composition of humic acids from Dzelve bogs

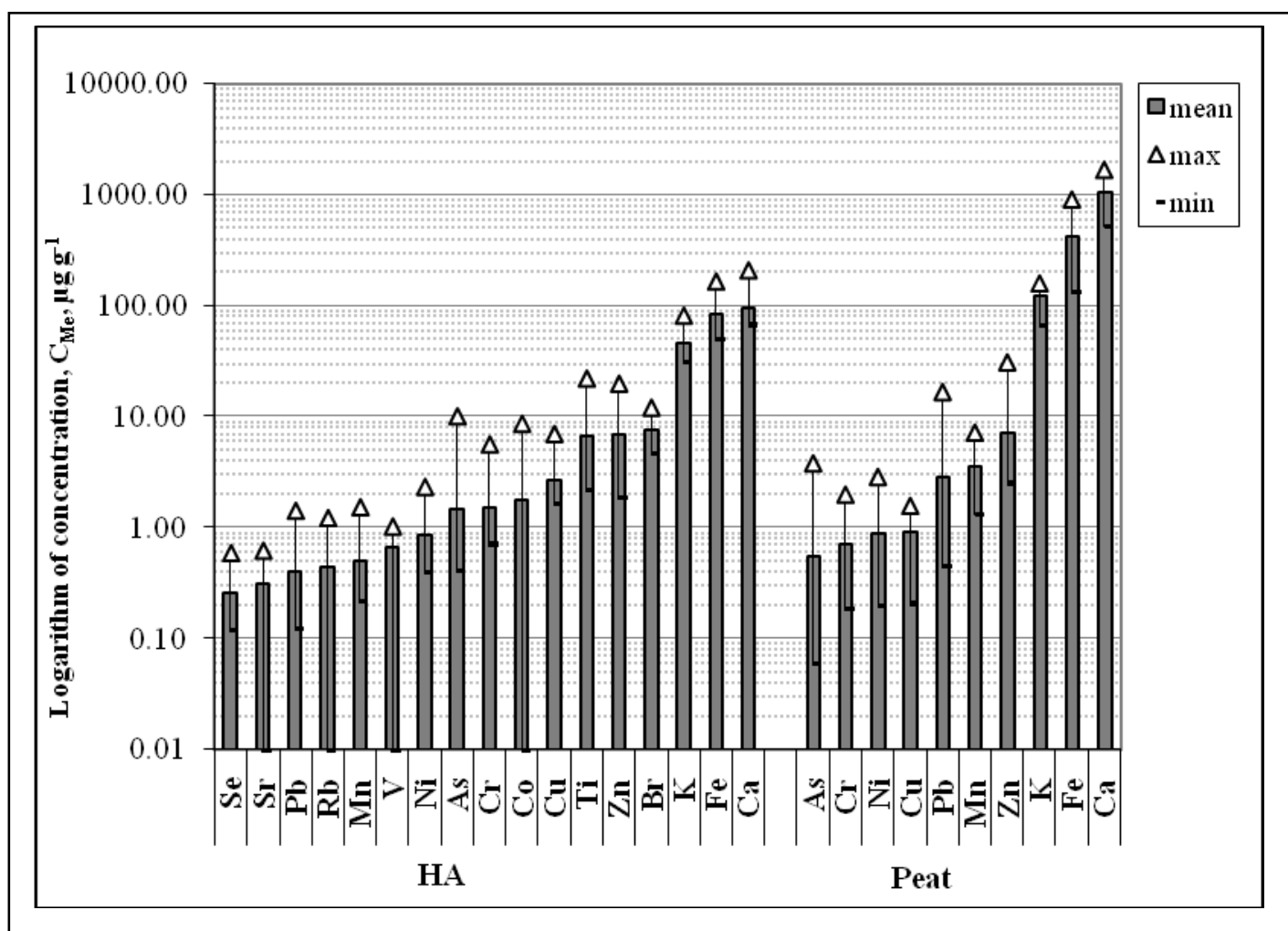

Fig. 3. Concentrations $\left(\mu \mathrm{g} \mathrm{g}^{-1}\right)$ of major and trace elements in peat and humic acids of Eipurs and Dzelve Bog

\section{Conclusions}

Eipurs and Dzelve Bog are located in lowlands, they are of similar origin (they developed due to ground paludification), but they have largely differing lithology. Both bogs are typical raised bogs and not presently, nor historically have not been affected by direct pollution sources. Data show that the iron concentration in peat bog Eipurs increases with increasing depth of peat, while metal $(\mathrm{Fe}, \mathrm{As}, \mathrm{Ca}, \mathrm{Cu})$ concentrations have high values of the depth range $3.5 \mathrm{~m}-4 \mathrm{~m}$ in Eipurs bog peat and humic substances. Ammount of carboxylic groups in HAs significantly correlates with decomposition degree of peat. Fen peat and ombotrophic peat which formed from sedge and pine-cotton-grass shows higher decomposition level. 


\section{References}

1. Fuchsman, C.H. Peat: Industrial Chemistry and Technology. Academic Press: N.Y., 1980.

2. Shotyk, W., Weiss, D., Appleby, P.G., Cheburkin, A.K., Frei, R., Gloor, M., Kramers, J.D., Reese, S., van der Knaap, W.O. History of atmospheric lead deposition since $12,370{ }^{14} \mathrm{C}$ yr BP from a peat bog, Jura Mountains, Switzerland. Science 281, 1998, p.1635 - 1640.

3. Shotyk, W. The chronology of antropogenic, atmospheric $\mathrm{Pb}$ deposition recorded by peat cores in three minerogenic peat deposits from Switzerland. The Science of the Total Environment 292, 2002, p. 19 - 31.

4. Orru H., Orru M. Sources and distribution of trace elements in Estonian peat. Global and Planetary Change 53, 2006, p. $249-258$.

5. de Vleeschouwer, F., Gerard, L., Goormaghtigh, C., Mattielli, N., le Roux, G., Fagel, N. Science of the Total Environment 377, 2007, p. $282-295$.

6. Gondar, D., Lopez, R., Fiol, S., Antelo, J.M., Arce, F. Characterization and acid-base properties of fulvic and humic acids isolated from two horizons of an ombrotrophic peat bog. Geoderma 126, 2005, p. 367374.

7. Zaccone, C., Miano, T.M., Shotyk, W. Qualitative comparison between raw peat and related humic acids in an ombrotrophic bog profile. Organic Geochemistry, 38, 2007, p. $151-160$.

8. Zaccone, C., Cocozza, C., Cheburkin, A.K., Shotyk, W., Miano, T.M. Distribution of As, Cr, Ni, Rb, Ti and $\mathrm{Zr}$ between peat and its humic fraction along an undisturbed ombrotrophic bog profile (NW Switzerland). Appl. Geochem. 23, 2008, p. 25 - 33.

9. Zaccone, C., Soler-Rovira, P., Plaza, C., Cocozza, C., Miano, T.M. Variability in As, Ca, Cr, K, Mn, Sr, and $\mathrm{Ti}$ concentrations among humic acids isolated from peat using $\mathrm{NaOH}, \mathrm{Na}_{4} \mathrm{P}_{2} \mathrm{O}_{7}$ and $\mathrm{NaOH}+\mathrm{Na}_{4} \mathrm{P}_{2} \mathrm{O}_{7}$ solutions. Journal of Hazardous Materials 167(1/3), 2009, p. 987 - 994.

10. Stevenson, F. J. Humus chemistry. N.Y.: J.Wiley, 1982.

11. Aiken, G.R. Isolation and concentration techniques for aquatic humic substances. In: Aiken, G.R. et al. (Eds.), Humic substances in soil, sediments and water, N.Y.: Wiley, 1985.

12. Falkowski, P., Scholes, R.J., Boyle, E., Canadell, J., Canfield, D., Elser, J., Gruber, N., Hibbard, K., Hogberg, P., Linder, S., Mackenzie, F.T., Moore, B., Pedersen, T., Rosenthal, Y., Tan, K.H. Humic matter in soil and the environment: Principles and Controversies. N.Y.: Marcel Dekker, 2003.

13. Tipping, E. Cation Binding by Humic Substances, Cambridge University Press, 2002.

14. Davies, G., Fataftah, A., Cherkasskiy, A., Ghabour, E.A., Radwan, A., Jansen, S.A., Kolla, S., Paciolla, M.D., Sein, L.T., Buermann, W., Balasubramanian, M., Budnick, J., Xing, B. Tight metal binding by humic acids and its role in biomineralization. J.Cham.Soc.Dalton Trans., 1997, p. 4047 - 4060.

15. Zhou, P., Yan, H., Gu, B. Competitive complexation of metal ions with humic substances. Chemosphere 58, 2005, p. 1327 - 1337.

16. Pourret, O., Davranche, M., Gruau, G., Dia, A. Rare earth elements complexation with humic acid. Chem. Geol. 243, 2007, p. $128-141$.

17. Riise, G., Salbu, B. Major and trace elements in standard and reference samples of aquatic humic substances determined by instrumental neutron activation analysis (INAA). Sci. Total Environ. 81/82, 1989 , p. $137-142$.

18. Fengler, G., Grossman, D., Kersten, M., Liebezeit, G. Trace metals in humic acids from recent Skagerrak sediments. Marine Pollution Bulletin 28, 1994, p. 143 - 147.

19. Kuske, E., Silamikele, I., Kalnina, L., Klavins, M. Peat formation conditions and peat properties: a study of two ombrotrophic bogs in Latvia. In: Klavins, M. (Eds.), Mires and peat. Riga, University of Latvia Press, 2010 , p. 56.

20. Silamikele, I., Nikodemus, O., Kalnina, L., Purmalis, O., Sire, J., Klavins, M. Properties of peat in ombrotrophic bogs depending on the humification process. In: Klavins, M. (Eds.), Mires and peat. Riga, University of Latvia Press, 2010, p. 71.

21. Krachler, M., Shotyk, W., Emons, H. Digestion procedures for the determination of antimony and arsenic in small amounts of peat samples by hydride generation - atomic absorption spectrometry. Anal. Chim. Acta 432, 2001, p. $303-310$.

22. MacCarthy, P. A proposal to establish a reference collection of humic materials for interlaboratory comparisons", Geoderma 16, 1976, p. 179-181.

23. Tan, K.H. Principles of soil chemistry. Marcel Dekker, Inc., New York, NY, 1982.

24. Schnitzer, M. Organic matter characterization. In: Miller, R.H., Keeney D.R. (Eds.), Methods of soil analysis. Agronomy series No. 9. American. Society of Agronomy, Madison, W.I., 1982, p. 581 - 594.

25. Cabaniss, S.E. Synchronous fluorescence spectra of metal-fulvic acid complexes. Environ. Sci. Technol. 26, 1992, p. $1133-1139$. 